\title{
Sourcing the Defining Business Idea
}

\section{The Defining Idea}

A defining idea can be characterized as a particular business, or product idea, that becomes central to the life of an entrepreneur and to the success of a company. It includes the product, or product line, that carries the company to success, regardless of whether this happened at the beginning, in the process of founding the company, or later on in the life of the firm. All companies covered by this research benefited at one time from such a defining idea, whether it came as a sudden Big Bang or in incremental steps, early or later in the company's life, externally sourced or internally derived.

Needless to say, this central or defining idea came to the firms' management in different forms. It seemed important to categorize the forms in order to demonstrate how these ideas were capitalized on. Some of the most intriguing aspects of the interviews, as retold in the company profiles, center around the stories behind the origin of a defining idea.

\section{Leaving Unresponsive Employer}

Quite a number of researched companies were created as a result of an entrepreneurial manager leaving his former employer, striking out on his own and developing a successful firm. This was a path taken throughout the period researched, involving both the oldest firm in the sample, Sefar, as well as a few of the younger ones. Founder Pierre Dufour was an employee-manager who split from a business owner and partner to set up an enterprise of his own; he went on to create Sefar, which is still active today. The idea for the business came through the association with his previous employer and partner.

The Bodmer family had been active in the silk industry for decades and were one of the wealthiest families of Zurich. In the 1820s, they hired the young and enterprising Pierre 


\begin{abstract}
A. Dufour (1797-1842) from Lyon, the capital of the European silk trade at that time, as a trading traveler. On behalf of Heinrich Bodmer, Pierre Dufour searched for possibilities of producing silk gauze in Switzerland. In 1830, Dufour succeeded in weaving the first silk bag cloth on a converted cotton loom of a weaver in the small village of Thal, in Eastern Switzerland, and subsequently started the production of silk bag cloth. However, in 1833, Dufour and Bodmer split up and Dufour founded his own company in Thal under the name Dufour \& Co., later to become Sefar. ${ }^{1}$
\end{abstract}

More than 100 years later, in the Eastern part of Switzerland, a similar trajectory can be observed: two optical engineers leaving their employer, going on to create their own company and benefiting from their technical experience in the optical field. They were helped by a friend who supplied the necessary capital for the company that was to become FISBA.

In 1957, FISBA co-founder Waldemar Striezel was working as an optical engineer at Wild Heerbrugg in the nearby Rhine Valley and he wanted to start his own company with his colleague Hennoch (Heni) Altherr. Wild was a precision engineering and optics company, which would be later sold to Leica, the large German manufacturer of optical microscopes. His friend Christian Fischbacher (1916-2006), who was running his own textile business, helped them and together they launched Altherr Striezel. A year after the launch, Christian Fischbacher acquired all shares of the company which was renamed FISBA. ${ }^{2}$

The story repeats itself, this time in the Western part of Switzerland, where engineers, building on their experience in a particular line of business, in this case measuring devices, developed improved products and started their own companies, in part due to unresponsive employers who had not been willing, or able, to capitalize on the new developments.

Hans Meyer left Tesa in 1972 and started, with some former Tesa colleagues, Trimos, a new company to produce a line of competitive measurement devices. He had separately started an engineering office in 1973 under the name of Sylvac where his son Hans-Ulrich developed electronic height measuring gauges. This operation was finally incorporated to form Sylvac SA in 1978 with Meyer father and son, plus some former Tesa managers, as shareholders. The main business of Sylvac consisted of selling electronic control units for measuring devices to Trimos, a company founded in 1972 and partially owned by the Meyers. ${ }^{3}$

Jean-Pierre Etter struck out on his own, founding LEM. Etter began by selecting just two of the patented ideas from the engineering consulting firm where he had worked previously for ten years, unsuccessfully trying to secure any large-scale adoptions of their inventions. With a view towards commercializing these ideas, he chose one which dealt with measuring electric current. ${ }^{4}$

\footnotetext{
${ }^{1}$ Adapted from Sefar company profile.

${ }^{2}$ Adapted from FISBA company profile.

${ }^{3}$ Adapted from Sylvac company profile.

${ }^{4}$ Adapted from LEM company profile.
} 
The experience of Paul Wyser, founder of Wyon, a producer of rechargeable batteries, is a more recent example of a manager leaving a technology-oriented company, the Swatch Group, when his business idea was turned down because it did not fit into the established corporate strategy.

\begin{abstract}
Wyon founder Paul Wyser had worked for Renata, a company now part of the Swatch Group. Originally, Renata produced mechanical watch components. With the growing importance of quartz watches, Renata built up the production of button cells for watches and became world leader in that market. When Renata was bought by the Swatch Group, Paul Wyser became a member of the extended management. In the 1990s, the company considered producing rechargeable batteries for the mobile phone sector in Switzerland. However, Paul Wyser was skeptical about this project because Asian firms had already been producing such batteries for five years. Instead, he proposed producing batteries for new applications in the medical sector, a market which Swatch did not want to enter. Paul Wyser had many business contacts in the battery related industries, including hearing aid specialist Phonak and he knew that there was a demand for rechargeable battery solutions in the medical industry. Thus, the basic idea for the company came from there and Wyon was formed in $1999 .^{5}$
\end{abstract}

The above examples (Sefar, FISBA, Mikrop, Sylvac, Wyon) demonstrate that in many established companies, projects for new business, or products, are often not pursued. Engineers or managers in those firms, who might not have seen themselves as entrepreneurs in a classical sense, were nevertheless entrepreneurial enough to move on and create new businesses. In the course of daily business, one might wonder how many such situations occur on a regular basis and how many opportunities might not be grasped and are overlooked?

Another set of ideas stemmed from distributors or sales representatives who realized that their product suppliers were not sufficiently responsive to the impulses of the customer base and thus took the initiative to create their own businesses. From the present research database, two companies were identified in which thriving businesses were created on the basis of filling a supply gap left unattended by existing suppliers. Filtrox furnishes an earlier story, Acutronic a more recent one to illustrate this point.

Hans Schmid, founder of Filtrox, had worked in Switzerland as a sales representative for Seitz, a German company and the inventor of depth filtration. Up until the 1930s, the Swiss beverage industry completely relied on imported depth filters. Presumably due to political developments in Germany and the threat of the borders being closed, Hans Schmid thought about founding a company for the production of filter media in Switzerland. In 1938, he signed a licensing agreement with a competing filter specialist from Germany to acquire the necessary expertise and went from being a salesman to being a producer. ${ }^{6}$

Leo W. Marxer (1931), who had worked for the US company Goerz Optical Co in the 1960s, won the contract to distribute Goerz motion simulators and founded Acutronic in 1973. The inability or unwillingness of the predominating American Motion Rate Table suppliers to

\footnotetext{
${ }^{5}$ Adapted from Wyon company profile.

${ }^{6}$ Adapted from Filtrox company profile.
} 
customize their products to local needs (i.e., local manufacturing, metric, customer support) created a great window of opportunity for the new company. In the 1980s, after a few years of being a distributor for Goerz, Acutronic got the chance to deliver position tables and become a maintenance repair organisation (MRO) for the European Tornado jet program. This was the kick-start for Acutronic as a manufacturer. Acutronic grew out of the Tornado business and in order to best serve Tornado clients all over Europe, subsidiaries were set up in Germany, France and the UK. Acutronic specialized in developing a wide range of motion simulators tailored to the needs of its European customers and established itself as the major supplier of such simulators in Europe. ${ }^{7}$

The origins of the defining ideas for these firms demonstrate that the daily work experience and industry environment can be a potent source of winning business concepts. It is a matter of capitalizing on such business experience, which might come at a later stage in a manager's, or engineer's career, provided they are able to switch from an employee to an entrepreneurial mindset.

\section{Capitalizing on Personal Experience}

Some company founders leveraged their defining business idea from a personal experience gained outside their normal business activities. Whether a result of luck, serendipity, or simply of an observant mind, and although being rare sources of ideas, these instances nevertheless deserve attention. They demonstrate that winning business ideas can be encountered anywhere, be it while taking a bath, walking across a parking lot, trying to master cables for a disco music business, or capitalizing on an educational degree program.

Ricola founder Emil Richterich (1901-1973) finished his apprenticeship as a baker and confectioner and opened his own bakery in 1930. It was said that Richterich, working hard, often felt tired and began taking herbal baths to relax himself. He began to experiment with herbs as a hobby before he actually turned it into a business. As a master baker, he knew how to deal with sugar, thus creating herbal sweets, which he sold regionally and directly to retailers. Over time, Richterich developed as many as 80 different herbal sweets. In the end, it was the original herbal drop that sold best and Richterich began to focus on it. ${ }^{8}$

Komax founder Max Koch, as a teenager, in his spare time ran a mobile company 'Discotheque Facilities'. The constant rewiring and reassembling of his equipment gave him the idea that an automated process could help with the crimping and reconnecting of the wiring. While a student at ETH he developed a car-mounted speed-measuring device. To make connecting easier, he developed and built an auxiliary device to cut the many copper cables to the correct length. This device, and the experience running the earlier disco business, lay at the heart of the Komax business. ${ }^{9}$

\footnotetext{
${ }^{7}$ Adopted from Acutronic company profile.

${ }^{8}$ Adapted from Ricola company profile.

${ }^{9}$ Adapted from Komax company profile.
} 
When Hans Oetiker (1918-2002) stepped out of his small workshop in a hillside in the town of Horgen, he was often bothered by the oil and gasoline spots left behind by cars parked in the driveway in front of his business. His quest for a solution that would prevent cars from leaking oil or gasoline eventually resulted in a thriving global business. His solution, for which he was granted a Swiss patent, was an ear-shaped clamp, referred to as an ear-clamp, for which he also adapted his stamping machine to allow for mass production of the clamps. The ear clamp was a global innovation that was to fuel the business for more than 25 years when a succession of follow-on clamp designs was introduced to the market. Over time, the company brought to market several generations of different clamps, which were partial improvements of earlier systems, or new models, for better inclusion in automatic clamping systems. ${ }^{10}$

In 1997, Daniel Ammann, Andreas Thiel and Jean-Pierre Wyss, three PhD-students at the ETH Zurich under the supervision of Professor Gerhard Tröster, decided to leave their academic studies to start u-blox for the purpose of developing and marketing electronic modules for producers of communications systems with early emphasis on miniaturized GPS-receiver-modules. The three students had studied an earlier invention and patent from the US. Realizing that then current GPS systems based on several satellites could take one to five minutes to be activated and required seven to eight to establish a true position, the student team found several algorithms to accomplish this faster, use less field intensity than previous systems, do with less electric field strength. ${ }^{11}$

Although only the source of the initial defining idea is addressed here, in all company examples, a number of necessary additional developments and engineering steps were taken in order for the founders to develop a marketable product and bring it to fruition. As these founders refined their ideas, they were driven by ample curiosity and perseverance. But what is outstanding here is their ability to envision a business idea out of experience or observation. They literally stumbled over, or into, the concept. In all three cases, there was an added element of previous experience, or a skill set, which, combined with the "Big Idea," created an eventual solution.

\section{Walk-Ins as Innovation Sources}

One of the first companies to be visited and interviewed was Plumettaz near Bex (VD). Going over the sources for the company's many innovations and changes in product line, covering almost 100 years, Denis Plumettaz surprised in the interview with an unusual story regarding the history of his company's success: "We are practicing the Open Eye Principle of innovation." Digging further, the experience with the man in the Rolls Royce surfaced. In the 1970s, Plumettaz had equipped many British Land Rovers with winches, some of them used by the British defense forces to tow trucks and tanks.

\footnotetext{
${ }^{10}$ Adapted from Oetiker Group company profile.

${ }^{11}$ Adapted from u-blox company profile.
} 
An engineer at the British Defense Ministry, who had become familiar with Plumettaz and its winches, had a friend whose business was to trade in patents. The two must have discussed Plumettaz because the British patent seller showed up one day at the Plumettaz factory in Bex: One day, a man drove in with his Rolls Royce and asked if we were interested in a patent that could improve gear box functions through a speed reducer for winching (Plumettaz, Executive Director). ${ }^{12}$

The Plumettaz engineers were intrigued enough to send one engineer to the UK plant that owned the patent. An exclusive licensing agreement was signed and the Plumettaz engineering team improved the idea to create its own Tranquart or Quadrant drive. This improvement of the gearbox, combined with its capstan drive technology, was leveraged to enter the staging market for the ever-growing number of skyscrapers that required difficult window cleaning. The Quadrant technology allowed for a much better control of the speed of the suspended gondolas from where crews had to work. In 1983, a licensing agreement was signed with a US supplier of stage-mounted traction hoists. Eventually, Plumettaz was to build and ship tens of thousands of these Quadrant gearboxes. ${ }^{13}$

The Open Eye Principle invoked by Denis Plumettaz was meant to indicate that there were many good ideas out there that could be the foundation of profitable and competitive businesses, or product ideas, provided that those hearing about them maintained an open mind and did not fall victim of the often quoted Not invented here $(\mathrm{NIH})$ principle. Once the research team's interest was piqued, it took a closer look at the idea sourcing practices in Plumettaz's history and found that the concept of the Open Eye had been employed by the company over decades, sustaining its innovation drive. Plumettaz and its innovation sourcing principles will also be returned to in a section below dealing with disruption.

The practice of capitalizing on new ideas at Plumettaz led to the firms' entry into the cable laying business. Again, there was a first request and then a workable engineering solution supplied, in addition to further requests that forced the company to continuously support improvements.

An opportunity arose from a business deal with the British Post Office. Owner of a large fleet of Land Rovers, the Post Office acquired Plumettaz capstan winches and retrofitted its Land Rovers for use in telephone cable laying operations. The conversion involved removing the front middle seat and installing a capstan winch in its place. ${ }^{14}$

From the telephone cable operations in the UK, it was a small step to the Swiss market, which led to a substantial growth in the cable laying business.

Plumettaz's entry into the telecommunications cable market began in 1980 with an initial order from the Swiss Telecom, then PTT, for three capstan systems for laying fiber optics cables. This was to be the beginning of a long-term partnership and a complete shift towards a new market segment. The laying of optical fiber cables posed unique challenges. While copper cables needed a manhole every 500 meters for access to join cables, fiber optic cables

\footnotetext{
${ }^{12}$ Adapted from Plumettaz company profile.

${ }^{13}$ Ibid.

${ }^{14}$ Adapted from Plumettaz company profile.
} 
used longer intervals. But the typical cable pulling mechanism proved ill-suited to the more fragile fiber cables. ${ }^{15}$

As Telecom companies throughout Europe were looking for solutions, experimenting with different technologies to lay fiber optic cables, Dutch Telecom had developed and patented an air blowing system that used a compressor to blow air through a tube holding the fiber. Again, it was Plumettaz that was faster in adopting this new technology and integrating it with its winching systems.

In 1990, the Dutch company first offered this technology to a German competitor of Plumettaz who declined the offer. When approached, Plumettaz, however, quickly realized the potential for significant efficiencies offered by this new method. Whereas winching could do about $15 \mathrm{~m}$ a minute, blowing could do $100 \mathrm{~m}$ in the same time. Plumettaz took out a 20-year license for Europe and Asia. An entire new line of products was developed and branded Cablejet. ${ }^{16}$

Blowing cables was not to be the end of the line for Plumettaz and its cable laying business. Once Plumettaz learned to drive cable installations by blowing rather than winching, it was natural to go to the next step and develop systems that used water as a driver for moving larger cables. In the process, Plumettaz built an entirely new competence around the jetting of cables, a long way from its original winching only for agricultural applications.

Having been exposed to the Plumettaz story of "The Man with the Rolls Royce," the research team's minds were open and alert to detect other similar situations that did, in fact, lead to central ideas around which entire businesses could and would be built. As it turned out, there were many of these stories, some of which were the basis of strong new businesses. For two companies, Jura and EAO, a single, external suggestion managed to give their businesses an entirely new direction, eventually leading to substantial growth and transformation.

\begin{abstract}
Jura, as early as 1937, had introduced an electric coffee percolator, which remained part of its portfolio for a long time. In 1976, Italian entrepreneur, Sergio Zapella, visited Jura to present his espresso coffee machine for in-home use. His company, SAECO, was the first to develop espresso machines for in-home use. Up to that time, the market was of the opinion that good espresso could only be made by professional machines in restaurants or coffee bars. When discussing the possibility of adding this SAECO machine to the Jura product line, the company's own marketing team considered the machine to be too expensive to produce. Testing at home by the company founders Henzirohs, and some company managers, led to the consensus to import the Italian machine for the Swiss market. In the process, Jura helped improve the SAECO machine in terms of quality and functionality and in return was granted the exclusive distribution rights for the Swiss market. The effort was successful and later Jura was to become focused entirely on espresso machines for in-home use. ${ }^{17}$
\end{abstract}

\footnotetext{
${ }^{15}$ Ibid.

${ }^{16}$ Ibid.

${ }^{17}$ Adapted from Jura company profile.
} 
At EAO, the Olten company specializing on push buttons owned its entry into this business to a customer's suggestion. Until that time, EAO was focused on transformers for electrical cabinets.

One day, an electrical cabinet maker who sourced transformers from EAO, told the company about the problems he had with switches in his cabinets. Thalmann, one of the two founders, who knew something about switches and push buttons, then developed a push button made from plastic materials, with a small lamp inside to light up. There were no such products on the market in 1958. The lighted buttons found success and the reaction of the founders was: "Let's go and make some more." The suggestion of the electrical cabinet maker, and the response of the two company founders Loosli and Thalmann, eventually led to the products around HMI that became the dominant business of EAO. ${ }^{18}$

For some companies, there were multiple events, or external sources, leading to new business ideas. For Kuhn Rikon, two different inventors came to offer their ideas to the company, both of which were accepted and implemented.

Kuhn Rikon's Duromatic, the pressure cooker with a spring valve to release pressure, was launched in 1949. It became a defining product, still accounting for some 20 percent of company sales (2017). The product resulted from a chance meeting between Jacques Kuhn and an inventor from Zurich. Realizing the value of this idea, Kuhn Rikon took out a license and combined it with a bayonet-closing device designed by Jacques Kuhn. A joint patent was issued for the closing device and the valve making the use of the Duromatic both simple and safe. ${ }^{19}$

Kuhn Rikon's entry into the kitchen gadget business was owed again to a contact with an external inventor. As the story goes, in 1982, an inventor from Biel showed up one day at Kuhn Rikon with a design for a can opener that cut underneath the can's rim and avoided common injuries from opening a can. The company saw potential in the idea and set up a licensing agreement. The product found quick acceptance and a Swiss retail chain ordered 100,000 units. Through a friend who had sourcing contacts in China, the can opener was improved in 1998, such that after cutting one could put the lid back on. The connection to sourcing the can openers in large quantities from China eventually led to all kitchen gadgets and utensils being source from there. ${ }^{20}$

Felco, the producer of pruning shears, also capitalized on the suggestions of customers from two sources in order to redefine its business. The company had its start in pruning loppers, made for pruning trees.

As the story goes, a wine grower approached Felco founder Flisch, asking for a hand-held pruner for his vines. Since he, Flisch, could make such good tools, maybe he could also make one for his use in the vineyard? The first design, named Model 1, made of forged aluminium and interchangeable parts, became an immediate success. Before long, other winegrowers asked for the same. Soon, a growing business developed for these pruning

\footnotetext{
${ }^{18}$ Adapted from EAO company profile.

${ }^{19}$ Adapted from Kuhn Rikon company profile.

${ }^{20}$ ibid.
} 
shears that have become the leading product for Felco. The follow-on model, Felco 2, has remained the company's bestseller since $1948 .{ }^{21}$

A second story, surrounding the introduction of cable cutters, began in a similar fashion. Someone came and said: "You know how to cut branches, why don't you build a tool to cut cables?" In response, Felco created a complete range of cable cutters in 1952, based upon a unique triangular cutting approach that allowed cables to be cut but not bent. The Felco cable cutters were used in many different applications, including automobile tire production, aerospace production and even some large ones used emergencies by sailing crews. ${ }^{22}$

Thermoplan, the makers of automatic coffee machines for the hospitality sector, hit a triple by capitalizing three times in a row on the suggestions of customers, each time giving the business an expanded direction. Founder Domenic Steiner entered the business of building and installing professional kitchens for institutional clients and the hospitality sector. Attending regular equipment fairs, Steiner heard about the problems faced by hotel and restaurant kitchens.

The first major idea came to Steiner during his many exchanges with other fair visitors. Thermoplan founder Steiner learned that whipping cold cream was a 'pain point' for restaurant and hotel owners. Together with a local mechanical workshop they solved the aeration problem and in 1983 brought a cold cream whipping device on the market. It was half the size of existing equipment, considerably more user friendly, and allowed for the connection of a TetraPak cream container. This simple device, branded 'S'Whipper,' conquered the world. ${ }^{23}$

The second major idea came in 1991, at another kitchen equipment show, when Steiner realized that the emerging trends towards cappuccino and caffe lattes would be a new opportunity for equipment to produce hot milk foam at the press of a button. Launched in 1993 under the brand name of 'Faomino,' Thermoplan's new equipment was designed on the same principles as its cold cream whipper. ${ }^{24}$

The third defining idea came in 1995 when Steiner, making his usual rounds at restaurant fairs talking to users of Thermoplan's cream whipping and hot milk foaming machines, was confronted with the suggestion that only coffee was missing from the mix. The development of an automatic coffee machine for use in restaurants and hotels, however, was to require a considerable investment. The project was not without risk as several professional automated coffee machines were already on the market. Domenic Steiner, the company's founder, nevertheless, decided to take this next step. Recruiting a suitable engineering team, the company worked on the project for two years. ${ }^{25}$

By following up three times in a row on market suggestions and successfully engineering solutions for those "pain points," Thermoplan grew the business to an annual production of more than 20,000 coffee machines shipped, employed some 300 people, and generated annual sales of CHF 300 million. In a later section, the

\footnotetext{
${ }^{21}$ Adapted from Felco company profile.

${ }^{22}$ Ibid.

${ }^{23}$ Adapted from Thermoplan company profile.

${ }^{24}$ Ibid.

${ }^{25}$ Ibid.
} 
company's use of codevelopment and alliances that contributed to the growth of the business will be featured.

\section{Power of Customer Suggestions}

The defining business ideas discussed in this section did not originate in classical research departments. These were external, customer supplied ideas, free of charge, but accepting these ideas required concerted action and effort on the part of company management. However, the question can be raised: How does a company have to organize itself in order that such external ideas are properly evaluated and their potential understood?

The impression that all a company needs to do is to wait for a customer to walk in with an insightful idea does not reflect the entire reality. There is no question that these ideas were important, but they only served as a trigger for the development of a workable engineering solution. At the companies, it sometimes took a considerable internal engineering effort to turn these ideas into the basis of sustained success. How the initial ideas were continuously updated, refreshed, and improved will be discussed in a following chapter.

\section{Just Reading About It}

Defining ideas do not always have to come from customers. Sometimes, new ideas can be gleaned from published materials or scientific journals, as was the case at Geistlich, the producer of regenerative biomaterials.

In the early 1980's, Peter Geistlich, CEO and Chairman of the Geistlich company, and an avid reader of scientific journals, came across an article in a US-based journal about synthetic bone materials for regeneration, to be used in dental surgery. At the time, bone replacement or enhancements involved bone grafts from the patient and required a highly involved procedure. However, it was essential for patients who did not have enough bone mass left in their jaws. One of the leading experts in this field was Professor Boyne from California. Peter Geistlich was immediately attracted to the ideas behind the article and was determined that bone augmentation for dental surgery could be achieved using material from natural bones. He sought a collaboration and engaged in joint research with Boyne. ${ }^{26}$

\section{Rejected Job Application}

Sometimes, even a rejected job application can lead to a business idea. This happened to Peter Grogg, founder of Bachem, upon his return to Basel after a long stay in the USA.

\footnotetext{
${ }^{26}$ Adapted from Geistlich company profile.
} 
Upon his return to Switzerland in 1971, Grogg, the eventual founder of Bachem, immediately applied for a job at Ciba, his previous employer. However, the company did not even bother to respond to his $\mathrm{CV}$ and job application letter. Grogg knew that research teams at Pharma companies produced their own peptides based on amino acid derivatives, a process he was familiar with from his US experience. Without a job offer, but undeterred, Grogg offered researchers he knew at Ciba to produce peptide synthesis needed for their research projects, thus taking away their 'pain' and freeing them from a time-consuming job and allowing them to instead focus on their research work. ${ }^{27}$

Grogg, getting no response for his job application, developed Bachem out of this, a highly successful company marketing its products globally to leading pharmaceutical research organizations and developing an entire industry sector as a result.

What would have happened if Ciba (today part of Novartis) had accepted Grogg's job application?

\section{Exploiting Disruptions}

When a customer walks in with a new idea, this turns out to be relatively benign and does not challenge the survival of the firm itself. When a competitor, or a new competitive constellation, is the source of the new idea, it is often referred to as innovative disruption. ${ }^{28}$ Several of the researched firms had experienced such disruptions. Their response, and how to capitalize on such events, is an important element in the longevity of some of these companies. Featured below are three companies that suffered from such an innovative disruption; each confronted the challenge in different ways.

Plumettaz, producer of winches, has served as an example for the Open Eye Principle in terms of responding to customer ideas. The company had already demonstrated how to integrate new technology solutions into its winching business, which was entirely focused on the vineyard sector.

When regular plowing of the vineyards was abandoned, the need to winch plows on tractors up and down steep vineyards became obsolete. This change of agricultural method impacted heavily on Plumettaz, at that time largely a supplier for vineyards. The company's experience with the tractor-mounted self-propelled winches based upon its capstan technology was used to explore other applications of similar type. The nearest, and most obvious, was found in the forest industry. Collaborating with the regional forestry services, the Plumettaz design office created two types of capstan winches to be integrated with Land Rovers, the fourwheel drive vehicle popular in forestry services and used for hauling timber onto the road. The installation of capstan winches onto Land Rovers brought Plumettaz to the attention of British Leyland, the manufacturer of Land Rovers. An initial order to equip scores of Leyland trucks were followed up by further orders, swelling the order books of Plumettaz. ${ }^{29}$

\footnotetext{
${ }^{27}$ Adapted from Bachem company profile.

${ }^{28}$ Christensen CM (1997) The innovator's dilemma: when new technologies cause great firms to fail. Harvard Business School Press, Brighton, MA.

${ }^{29}$ Adapted from Plumettaz company profile.
} 
As documented earlier in this chapter, Plumettaz's British connection was to prove important because it took the company out of purely agricultural applications and into new fields that changed the course of the company. By 1973, the anniversary of Plumettaz's 50th year, company sales for nonwine-growing use of its winches exceeded, for the first time, wine-growing applications. This was a trend that continued, and by 2018, wine-growing sales represented only a very small percentage of company activities. This was achieved because Plumettaz continuously grabbed opportunities — be they welcome or imposed-from external sources, incorporating them into its business. Without having done so over its decades-long history, the company would have suffered from mortal disruption years ago.

Disruption can also be caused when parts of a company's business are sold, which is the story behind maxon's development and later success. Created in 1963, under the name of Interelectric, ${ }^{30}$ the company's first mandate was to produce shearing foils for Braun, the parent company's electric razor. When Braun decided to divest its electric razor business to Gillette in 1967, the business located in central Switzerland lost its main internal customer.

\begin{abstract}
At maxon, an internal development team had begun work on further developing small electric motors intended for eventual use in Braun razors, stemming from a project undertaken at Braun even prior to starting-up the Swiss foil production. With the loss of its razor shearing foils business, the company owners asked the team to intensify the development of small electric motors which could be the basis of a new business orientation and capitalize on the earlier development of a hand-operated small appliance. In the short period of about two years, the design team developed a range of small electric DC motors, including a patented process for an ironless rotor which doubled the efficiency of motors available based upon standard technologies, as well as extended the product service life. The product range 'maxon' stemmed from a combination of the name 'Max Braun \& Söhne.' The new line was launched in 1969, just two years after the sale of the shearing foil business to Gillette. ${ }^{31}$
\end{abstract}

One is reminded of the saying necessity is the mother of invention. The threat of innovation disruption is particularly acute for a company with an ongoing business facing substitution, or sidelining, through a larger company that could eliminate its competitive advantage. That this might happen once is one thing. But when it happens twice in a row, an SME is truly challenged to respond. Such was the case at Fraisa, the metal tool manufacturer which suddenly saw its business existence at stake. The challenge did not come from a competing toolmaker, but a company producing coatings for tools to extend their life. How Fraisa owners and managers responded is a stellar example of gutsy business survival decisions.

Fraisa's owner Hans Stüdeli was quick to react when, in 1980, Balzers, a Liechtensteinbased company, demonstrated a new technology for surface hardening of metal tools, extending their useful life. Already the first generation of this thin film coating technology,

\footnotetext{
${ }^{30}$ The name maxon Motor was adopted only years later as company name. Its motors had earlier been branded maxon. Most recently, the company name was changed solely to maxon.

${ }^{31}$ Adapted from maxon company profile.
} 
called PVD coating, extended tool life by a factor of 0.5 , and coated tools could operate 1.5 times faster than standard steel tools. The 2 nd generation extended tool life by a factor of ten and allowed to operate 2.5 times faster in comparison to uncoated tools.

Fraisa's owner was quick to see both the potential and threat of this new technology, and that this could radically change the tool industry. Fraisa became the first end mill manufacturer to adopt this new coating technology, which, since applied at the end of the tool production process, required Fraisa to understand vacuum coating technology. Fraisa thus became the first tool making company to adopt coating, while other firms in the same industry were hesitant to take the step. In addition, Stuideli priced the coated tools at a premium of only 1.5 times the price of regular tools for the first generation, and 2.5 times for the second generation, something that other tool makers could not understand. They pushed Stüdeli in vain to increase his prices.

A customer who buys this tool will not soon buy another tool. If we do not adopt this new technology, another company surely will. Customers will save on machines by buying fewer machines. They will not save on tools because their speed was up. Self-cannibalization is better than being cannibalized (Maushart, CEO, quoting company founder Stüdeli). ${ }^{32}$

A few years later, Fraisa was once more confronted with a threatening development, this time on the material side. Over time, materials harder than steel became increasingly used in the industry, changing the requirements for the tools used to work on them. Newer, harder metals required new cutting materials for the cutting tools. Fraisa had, at first, hesitated to respond, leading to a loss of competitiveness and loss of sales. A young development team was tasked in 1990 to find a response for the company.

Josef Maushart, a 25-year old engineer, who was later was to become CEO and owner of Fraisa, joined the group in 1990 tasked with developing hard metal tools. "We were behind, almost too late" he recalled. The team decided to respond by coming up with a next generation tool, leapfrogging developments and avoiding mistakes made by the pioneers. With a new industrial norm for hard metal to meet (DIN), the young team was able to present their first solution in Hanover in 1993, and tools for high-speed cutting for aluminum and steel at the Milano Fair in 1995. Despite the late start, the entry into the age of hard metals had been accomplished after all. ${ }^{33}$

The examples of Plumettaz, maxon, and Fraisa tell us that even when a market appears lost, or an entire industry shifts, this can be the beginning of something new.

\section{Borrowing from Other Industries}

So far, the sourcing of ideas has relied on customers bringing in new ideas, unresponsive employers being left or disruptive developments necessitating new answers. There is, of course, another source of ideas: observing other industries and

\footnotetext{
${ }^{32}$ Adapted from Fraisa company profile.

${ }^{33}$ ibid.
} 
transferring industry practices, not out of necessity but in order to capture an opportunity. Although this did not happen frequently among the researched companies, there was one example that does come to mind, Felchlin, the supplier of chocolate specialties for praline couverture. In its search for differentiation, the company adopted the Grand Cru story from the coffee industry, and the single malt approach for whiskey, and applied it to cacao bean selection and processing.

Traditionally, industry treated all cocoa beans essentially as a commodity. Felchlin decided to take a page out of different industries and to develop a chocolate product line made from distinct, labeled and identified beans, such as was the case in the coffee industry. The Felchlin team was intent on going back to the roots of cocoa and identify special growers in South America who were small-lot farmers organized into cooperatives. The resulting Grand Cru Selection consisted of single origin couverture, similar to single malt spirits. The process of moving into the Grand Cru product line was accelerated in 1999 with the launch of the single origin couvertures, eventually leading to some 25 different crus, differentiated into many different levels of cacao, flavor intensity, milk intensity, plus vegan or lactose free combinations. $^{34}$

To market these specialties, a new language had to be created. For that purpose, Felchlin leveraged the experience of the agricultural and winegrowing department of the University of Applied Sciences in Wädenswil. Together with the school, Felchlin developed a language to describe the taste differences of chocolate and cocoa beans. ${ }^{35}$

The adoption of the Grand Cru strategy was not forced upon Felchlin, and its adoption was not triggered by any particular industry turmoil. What this process demonstrates is the richness of new ideas to be harvested by open-minded company founders willing to look beyond their own industry barriers.

\section{Practicing the Open Mind Principle}

Reviewing the many different sources of new ideas demonstrates the eclectic beginnings of many of the SMEs documented in this book. The defining ideas were gleamed through observations and did not come as a result of formal research or tabulating surveys. The ideas were not the result of planned research. Rather, the company founders connected the dots between a number of developments in the market where many others, confronted with the same realities, did not see any new business opportunities. The further development of these ideas still took time to accomplish, and once a business started to grow around that initial idea, more formal development efforts were added to support it. Keeping an open mind, open eyes, and even open ears was, and remains to this day, the principal means for the SME founders to launch their companies.

\footnotetext{
${ }^{34}$ Adapted from Felchlin company profile.

${ }^{35}$ Ibid.
} 
Open Access This chapter is licensed under the terms of the Creative Commons Attribution 4.0 International License (http://creativecommons.org/licenses/by/4.0/), which permits use, sharing, adaptation, distribution and reproduction in any medium or format, as long as you give appropriate credit to the original author(s) and the source, provide a link to the Creative Commons license and indicate if changes were made.

The images or other third party material in this chapter are included in the chapter's Creative Commons license, unless indicated otherwise in a credit line to the material. If material is not included in the chapter's Creative Commons license and your intended use is not permitted by statutory regulation or exceeds the permitted use, you will need to obtain permission directly from the copyright holder.

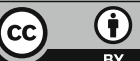

